\title{
Opioids Excite Dopamine Neurons by Hyperpolarization of Local Interneurons
}

\author{
S. W. Johnson and R. A. North \\ Vollum Institute, Oregon Health Sciences University, Portland, Oregon 97201
}

\begin{abstract}
Increased activity of dopamine-containing neurons in the ventral tegmental area is necessary for the reinforcing effects of opioids and other abused drugs. Intracellular recordlings from these cells in slices of rat brain in vitro showed that opioids do not affect the principal (dopamine-containing) neurons but hyperpolarize secondary (GABA-containing) interneurons. Experiments with agonists and antagonists selective for opioid receptor subtypes indicated that the hyperpolarization of secondary cells involved the $\mu$-receptor. Most principal cells showed spontaneous bicuculline-sensitive synaptic potentials when the extracellular potassium concentration was increased from 2.5 to 6.5 or $\mathbf{1 0 . 5}$ mM; these were prevented by $T T X$ and assumed to result from action potentials arising in slightly depolarized local interneurons. The frequency of these synaptic potentials, but not their amplitudes, was reduced by opioids selective for $\mu$-receptors. It is concluded that hyperpolarization of the interneurons by opioids reduces the spontaneous GABAmediated synaptic input to the dopamine cells. In vivo, this would lead to excitation of the dopamine cells by disinhibition, which would be expected to contribute to the positive reinforcement seen with $\mu$-receptor agonists such as morphine and heroin.
\end{abstract}

The dopamine-containing neurons of the midbrain ventral tegmental area (VTA) play a critical role in the reinforcing effects of drugs of abuse (Fibiger and Phillips, 1986; Wise, 1988; Liebman and Cooper, 1989). Behavioral experiments show that rats quickly learn to move to a location associated with previous heroin injections (Bozarth and Wise, 1981a); this conditioned place preference can also be produced by microinjection of opioids directly into the VTA, and it can be prevented by neurochemical destruction of the dopamine neurons (Phillips and LePiane, 1980; Phillips et al., 1983). Animals will repeatedly press levers to trigger microinjection of opioids or to stimulate electrically the VTA, and these behaviors also require intact dopamine neurons (Corbett and Wise, 1980; Phillips and LePiane, 1980; Bozarth and Wise, 1981b; Phillips et al., 1983; Fibiger et al., 1987). Opiates and other drugs of abuse increase dopamine release and turnover in the nucleus accumbens (Phillips and Fibiger, 1978; Smith and Lane, 1983; Di Chiara and Imperato, 1988), suggesting that the reinforcing effect of opiates

Received July 3, 1991; revised Sept. 9, 1991; accepted Sept. 18, 1991.

We thank A. Surprenant for help with data analysis. This work was supported in part by the American Academy of Neurology and U.S. Department of Health and Human Services Grants NS01423, DA03161, and MH40416.

Correspondence should be addressed to $\mathrm{R}$. A. North at the above address.

Copyright (C) 1992 Society for Neuroscience $0270-6474 / 92 / 120483-06 \$ 05.00 / 0$ is mediated by an increase in the output of dopamine. Finally, opiates administered systemically increase the firing of VTA dopamine neurons recorded in vivo (Nowycky et al., 1978; Matthews and German, 1984), although they inhibit the firing of nondopamine VTA neurons (Gysling and Wang, 1983).

The direct action of opioids on neurons elsewhere in the nervous system, including other catecholamine-containing cells, is inhibitory (North and Tonini, 1977; Williams et al., 1982; Mihara and North, 1986; North et al., 1987; Miyake et al., 1989; reviewed by North, 1992). This raises the possibility that the excitatory effect of the opioids on the principal, dopamine-containing cells occurs indirectly; that is, opioids may inhibit nondopamine neurons in the VTA (secondary neurons) that provide inhibitory synaptic input to the dopamine cells, as suggested by Gysling and Wang (1983). Therefore, we tested the hypothesis that opioids excite VTA neurons because they hyerpolarize local inhibitory interneurons.

\section{Materials and Methods}

Tissue preparation. A detailed description of the methods has been published elsewhere (Lacey et al., 1989). Briefly, male Sprague-Dawley rats $(180-300 \mathrm{gm})$ were anesthetized with halothane and killed by a blow to the chest. A horizontally cut slice of midbrain (thickness, 300 $\mu \mathrm{m})$ was submerged in a continuously flowing solution $(2 \mathrm{ml} / \mathrm{min})$ of the following composition (in mM): $\mathrm{NaCl}, 126 ; \mathrm{KCl}, 2.5 ; \mathrm{NaH}_{2} \mathrm{PO}_{4}, 1.2$; $\mathrm{MgCl}_{2}, 1.2 ; \mathrm{CaCl}_{2}, 2.4$; glucose, $11 ; \mathrm{NaHCO}_{3}, 18$; gassed with $95 \% \mathrm{O}_{2}$ and $5 \% \mathrm{CO}_{2}$ at $36^{\circ} \mathrm{C}, \mathrm{pH} 7.4$. The VTA was identified as the region lateral to the fasciculus retroflexus and medial to the medial terminal nucleus of the accessory optic tract (Paxinos and Watson, 1986). Cells in the zona compacta of the substantia nigra, which appeared as a crescent-shaped semilucent region rostral and caudal to the medial terminal nucleus, were not studied.

Intracellulur recording. Intracellular recordings were made with glass microelectrodes containing potassium chloride ( $2 \mathrm{M}$; resistance $40-90$ $\mathrm{M} \Omega$ ) or potassium acetate $(2 \mathrm{M}, 80-180 \mathrm{M} \Omega)$. Membrane potentials were amplified with an Axoclamp $2 \mathrm{~A}$ amplifier and recorded on a Gould 2400 recorder. In some experiments, potentials were recorded on a Vetter PCM data recorder (Rebersburg, PA) for later playback on a strip chart recorder. Input resistance was measured from the amplitude of small ( $<15 \mathrm{mV}$ ) hyperpolarizing electrotonic potentials. Reversal potentials were estimated from $\left(E_{m 2}-E_{m 1}\right)=\left(1-R_{2} / R_{1}\right)\left(E_{\mathrm{Rev}}-E_{m 1}\right)$, where $E_{m 1}$ and $E_{m 2}$ are membrane potentials in the absence and presence of opioid, $R_{1}$ and $R_{2}$ and are the corresponding input resistances, and $E_{\mathrm{Rev}}$ is the estimated reversal potential (Morita et al., 1982).

Evoked synaptic potentials. As described previously (Johnson and North, 1991), focal electrical stimulation with bipolar tungsten electrodes evoked a short-latency $(<3 \mathrm{msec})$ synaptic potential that could be separated into two components. One was mediated by excitatory amino acids, and the other, by GABA acting at $\mathrm{GABA}_{\mathrm{A}}$ receptors. When studying the synaptic potential mediated by excitatory amino acids, recordings were made with bicuculline $(30 \mu \mathrm{M})$ or picrotoxin $(100 \mu \mathrm{M})$ to block the $\mathrm{GABA}_{\mathrm{A}}$ component. When studying the synaptic potential mediated by $\mathrm{GABA}_{\mathrm{A}}$ receptors, recordings were made with the excitatory amino acid antagonists 6-cyano-2,3-dihydroxy-7-nitroquinoxa- 
A
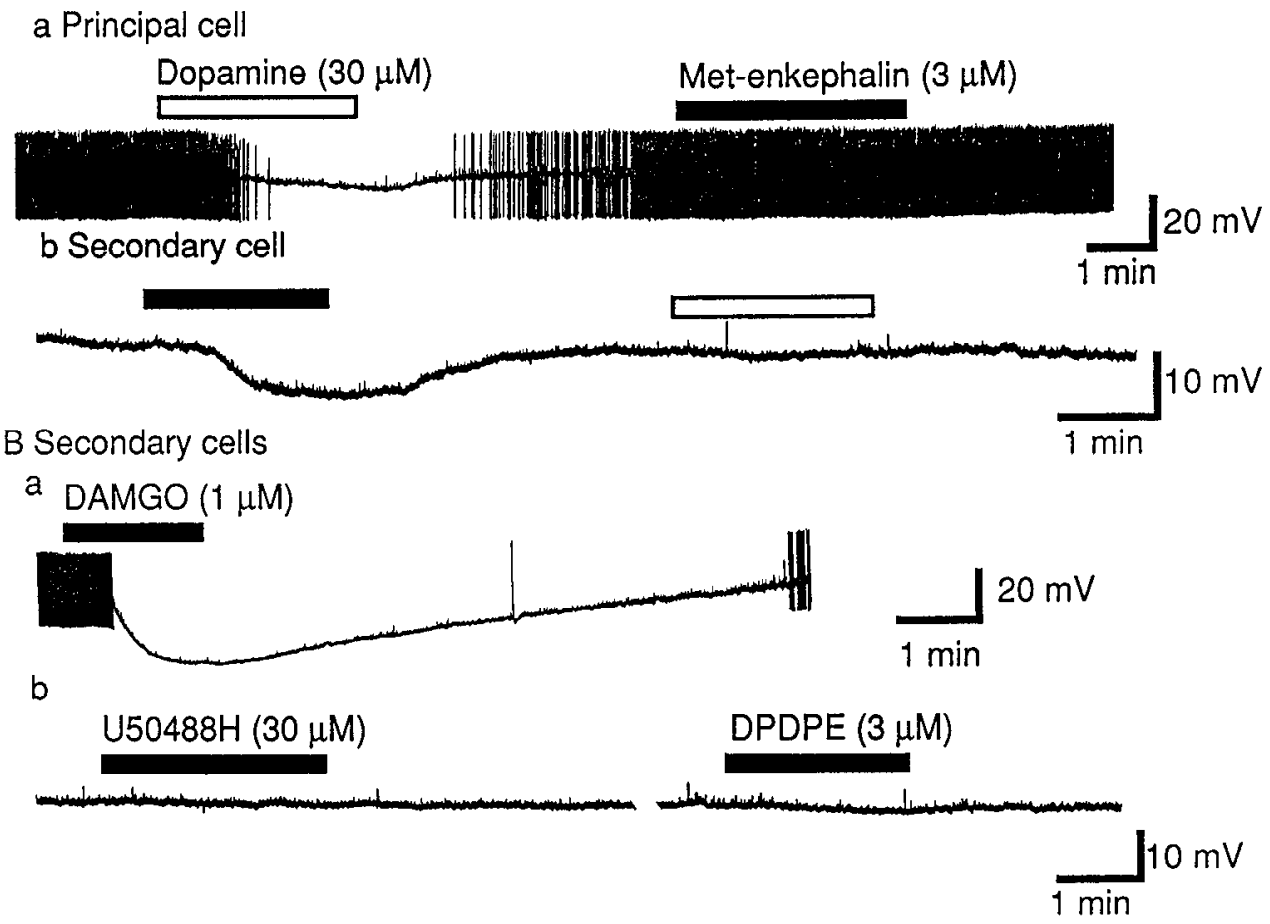

Figure 1. Hyperpolarization of secondary cells by $\mu$-receptor agonist. $A$, A Principal cell is hyperpolarized by dopamine but not [Mets] enkephalin $(a)$ and a Secondary cell is hyperpolarized by [Met $\mathrm{M}^{5}$ enkephalin but not by dopamine $(b)$. As shown here, principal cells usually fired spontaneously in vitro whereas secondary cells did not. $B, \mathrm{Hy}$ perpolarization of a Secondary neuron by the $\mu$-receptor agonist DAMGO (TyrD-Ala-Gly-MePhe-Gly-ol) (a) compared with lack of effects of $\delta$-receptor agonist DPDPE (Tyr-D-Pen-Gly-Phe-DPen) and $\kappa$-selective agonist U50488H $(b$, same cell as in $A b)$.

line (CNQX; $10 \mu \mathrm{M}$ ) and 2-amino-5-phosphonopentanoic acid (APV; $30 \mu \mathrm{M})$. In about $90 \%$ of cells, a train of stimuli $(5-10$ stimuli at $70 \mathrm{~Hz}$, delivered every $0.016 \mathrm{sec}$ ) evoked a late (latency $>50 \mathrm{msec}$ ) hyperpolarizing synaptic potential that was mediated by $\mathrm{GABA}_{B}$ receptors. This hyperpolarizing potential was routinely recorded in APV $(30 \mu \mathrm{M}), \mathrm{CNQX}$ $(10 \mu \mathrm{M})$, and picrotoxin $(100 \mu \mathrm{M})$.

Drugs. All drugs were applied by superfusion. Solutions containing drugs entered the recording chamber within $30 \mathrm{sec}$ of turning a tap, the delay being necessary for passage of the solution through a heat exchanger. Complete exchange of the bath solution occurred within 2 min. A stock solution of dopamine hydrochloride (Sigma) was made daily and kept on ice to retard oxidation. Other drugs used were $( \pm)$-bicuculline methiodide (Sigma), picrotoxin (Sigma), APV (Research Biochemicals), CNQX (Research Biochemicals), 2-hydroxysaclofen (saclofen; Research Biochemicals), $\gamma$-amino- $n$-butyric acid (GABA; Sigma), [Met ${ }^{5}$ ]enkephalin acetate (Tyr-Gly-Gly-Phe-Met; Sigma), tetrodotoxin (Sigma), DAMGO [(Tyr-D-Ala-Gly-MePhe-Gly-ol); Peninsula Laboratories], DPDPE (Tyr-D-Pen-Gly-Phe-D-Pen; Peninsula), U50488H (trans-3,4-dichloro- $N$-methyl- $N$-(2-(1-pyrolidinyl)-cyclohexyl)-benzeneacetamine; gift from Upjohn), naltrindole hydrochloride (Research Biochemicals), and CTOP ([Cys $\left.{ }^{2}, \mathrm{Tyr}^{3}, \mathrm{Orn}^{5}, \mathrm{Pen}^{7}\right]$ somatostatin-amide; Peninsula).

\section{Results}

Opioid hyperpolarization of secondary cells

Intracellular recordings from the VTA showed two types of cell, as previously described in the substantia nigra (Lacey et al., 1989). Seventy-one cells were tested with dopamine $(30 \mu \mathrm{M})$ and $\left[\mathrm{Met}^{5}\right.$ ]enkephalin $(30 \mu \mathrm{M}): 46$ cells were hyperpolarized by dopamine but not by [Mets]enkephalin (principal cells, Fig. $1 A$ ), 15 cells were hyperpolarized by [Met ${ }^{5}$ ]enkephalin but not by dopamine (secondary cells, Fig. $1 A$ ), and 10 cells were not classified. Secondary cells had relatively narrow action potentials (mid-spike width $<0.7 \mathrm{msec}$ ) and are presumed to be neurons that do not contain dopamine (Grace and Bunney, 1980, 1983; Grace and Onn, 1989; Lacey et al., 1989; Johnson and North, 1992; Yung et al., 1991). The sensitivity to opioids of the nondopamine cells is consistent with autoradiographic studies showing that $\mu$-receptor binding in the VTA is not changed by destruction of dopamine-containing cells (Dilts and Kalivas, 1989).

The hyperpolarization of secondary cells was mediated by activation of $\mu$-receptors, because the $\mu$-selective agonist DAMGO was highly effective (Fig. $1 B$ ) whereas agonists selective for $\delta$-receptors (DPDPE; $3 \mu \mathrm{M} ; n=3$ ) and $\kappa$-receptors (U50488H; $30 \mu \mathrm{M} ; n=3$ ) were ineffective (Fig. 1B). DAMGO at $100 \mathrm{~nm}$ hyperpolarized the membrane $2 \pm 1 \mathrm{mV}(n=3) ; 300 \mathrm{~nm}$ produced a $7 \pm 2 \mathrm{mV}$ hyperpolarization $(n=3)$, and $1 \mu \mathrm{M}$ causcd a $12 \pm 4 \mathrm{mV}$ hyperpolarization $(n=6)$. The hyperpolarization produced by [Met ${ }^{5}$ ]enkephalin was prevented by the $\mu$-receptor antagonist CTOP (300 nM; $n=4$ ) (Gulya et al., 1986) but was unaffected by the $\delta$-receptor antagonist naltrindole $(1 \mu \mathrm{M} ; n=$ 3) (Portoghese et al., 1988). The hyperpolarization resulted from an increase in membrane potassium conductance because it was associated with a decrease in neuron input resistance and had an estimated reversal potential of $-105 \pm 6 \mathrm{mV}(n=4$; this and other values are mean \pm SEM).

\section{Opioid inhibition of spontaneous inhibitory synaptic potentials}

The possibility was next investigated that the secondary neurons provided inhibitory input to the principal neurons; in this case, hyperpolarization of the inhibitory interneurons by opioids could be the explanation for excitation of the principal dopaminecontaining cells. Spontaneous synaptic potentials occurred in about $50 \%$ of principal cells when the extracellular potassium concentration was increased (from 2.5 to 6.5 or $10.5 \mathrm{~mm}$ ). These potentials were depolarizing when recording electrodes contained potassium chloride (reversal potential, estimated by extrapolation, was $-22 \pm 4 \mathrm{mV}, n=5$; Fig. 2) and hyperpolarizing when electrodes contained potassium acetate (reversal potential was $-79 \pm 6 \mathrm{mV}, n=4$; data not shown). The spontaneous depolarizing synaptic potentials were often several millivolts in 
A

a

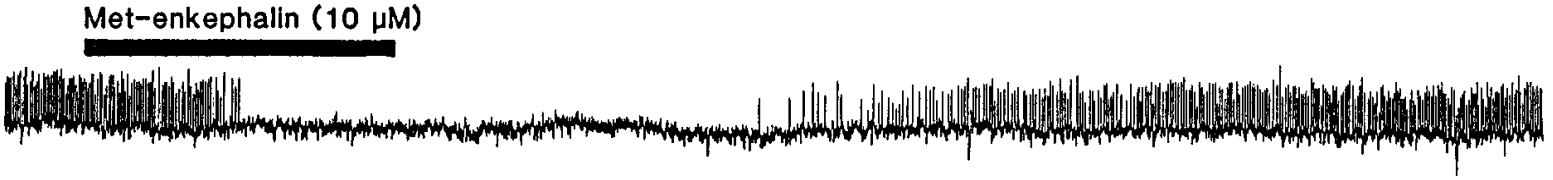

b

Bicuculline $(30 \mu \mathrm{M})$



(nd

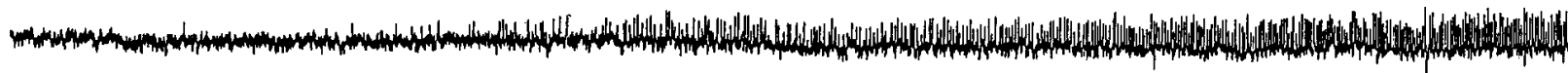
$\int_{10 \mathrm{~s}} 5 \mathrm{mV}$

a Control

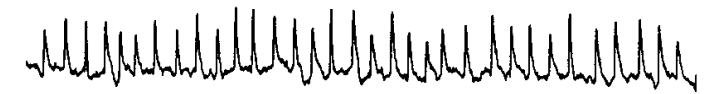

Met-enkephalin

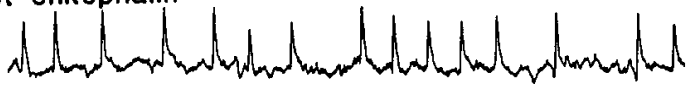

Wash



b

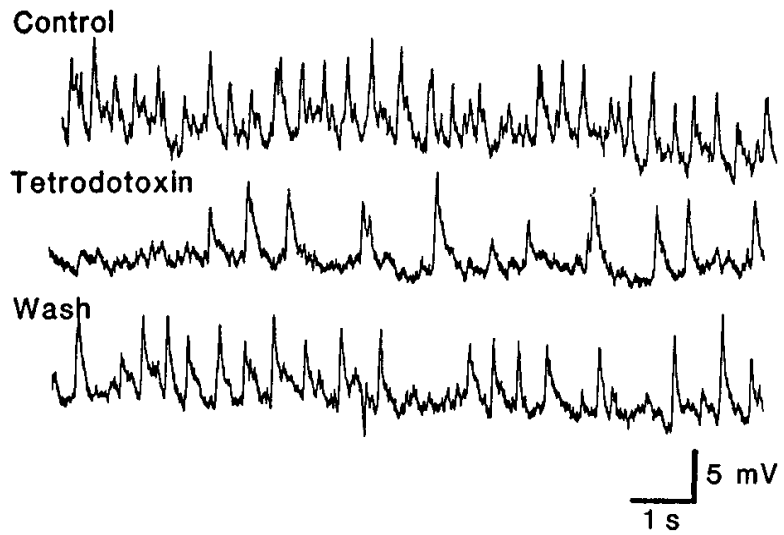

Figure 2. Opioids reduce the frequency of spontaneous GABA-mediated synaptic potentials. Synaptic potentials are depolarizing because recordings were made with an electrode containing potassium chloride. $A$, A high concentration of [Met ${ }^{5}$ ]enkephalin blocks spontaneously occurring synaptic potentials without changing their amplitude $(a)$ whereas bicuculline progressively reduces the amplitude of the synaptic potentials until they disappear $(b) . B$, The reduction in frequency of spontaneous synaptic potentials observed with a low concentration of [Met ${ }^{5}$ ]enkephalin $\left(100 \mathrm{nM}^{2}\right.$, $a)$ is mimicked by a submaximal concentration of TTX $(100 \mathrm{nM}, b)$. Higher concentrations $(1 \mu \mathrm{M})$ of TTX completely blocked spontaneous synaptic potentials.

amplitude, allowing single inputs to be discriminated from the amplitude histogram (Figs. 2, 3).

Bicuculline (10-30 $\mu \mathrm{M} ; n=7)$ progressively reduced the amplitude of spontaneous potentials until they completely disappeared (Figs. $2 A b, 3 A$ ). In contrast, a low concentration of TTX $(100 \mathrm{nM} ; n=6)$ reduced their frequency without affecting their amplitude (Fig. 2Bb) whereas a higher concentration $(1 \mu \mathrm{M})$ completely blocked the spontaneous potentials. Similar to TTX, [ $\left.\mathrm{Met}^{5}\right]$ enkephalin $(0.1-10 \mu \mathrm{M})$ reduced the frequency of spontaneous synaptic potentials without affecting their amplitude (Figs. 2, 3). This was likely to be a presynaptic action because $\left[\mathrm{Met}^{5}\right.$ ]enkephalin $(10 \mu \mathrm{M})$ had no effect on the membrane potential changes produced by exogenously applied GABA ( $1 \mathrm{mM}$; $n=4)$ or muscimol $(10 \mu \mathrm{M} ; n=3)$. DAMGO (100 nM) mimicked the effect of [Met'] ${ }^{\text {s }}$ kephalin by reducing the frequency of spontaneous synaptic potentials by $88 \pm 6 \%(n=3)$. Moreover, inhibition of spontaneous synaptic potentials by [Mets]enkephalin was blocked by CTOP ( $300 \mathrm{nM})$ but not by naltrindole $(1 \mu \mathrm{M})(n=1)$. Therefore, $\mu$-opioid receptors mediate both the suppression of spontaneous synaptic potentials and the hyperpolarization of secondary cells; the concentration of enkephalin needed to produce these two effects was similar, with a $50 \%$ maximal effect for each of about $1 \mu \mathrm{M}$ (Fig. 3B). The lack of effect of opioids on the amplitude of the spontaneous synaptic potential suggests that they reduce the frequency of firing of interneurons by hyperpolarization, rather than reducing the amount of GABA released by each action potential.

The excitation by opioids that is seen in vivo is probably not seen in vitro because of the loss of tonic activity through deafferentation. To test this, we recorded from principal cells with potassium acetate-filled electrodes and increased the inhibitory effect of local interneurons by increasing the extracellular potassium concentration (6.5-10.5 mM). In these conditions, [Met ${ }^{5}$ ]enkephalin $(10$ or $30 \mu \mathrm{M})$ and DAMGO (1 and $\left.3 \mu \mathrm{M}\right)$ depolarized and excited the cells (Fig. 4; four of five ncurons tested). This excitation resulted from reduced GABA release from interneurons because it was mimicked by bicuculline ( 10 or $30 \mu \mathbf{M} ; n=4$ ).

\section{Opioid inhibition of evoked synaptic potentials}

At low concentrations of [ $\left.\mathrm{Met}^{5}\right]$ enkephalin $(0.1-1 \mu \mathrm{M})$, there was no effect on the $\mathrm{GABA}_{\mathrm{A}}$ receptor-mediated synaptic potential when evoked by electrical stimulation. Only at high concentrations (3-30 $\mu \mathrm{M}$ ) was the synaptic potential depressed, and then maximally by $41 \%$ (Fig. $3 B$ ). The excitatory amino acid component of the synaptic potential was also reduced by high concentrations of [ $\left.\mathrm{Met}^{5}\right]$ enkephalin; inhibition was $5 \pm 9 \%(n=5)$ by $3 \mu \mathrm{M}, 14 \pm 12 \%(n=6)$ by $10 \mu \mathrm{M}$, and $34 \pm 13 \%(n=6)$ by $30 \mu \mathrm{M}$. Similarly, the hyperpolarizing synaptic potential mediated by $\mathrm{GABA}_{\mathrm{B}}$ receptors was reduced by high concentrations 
A

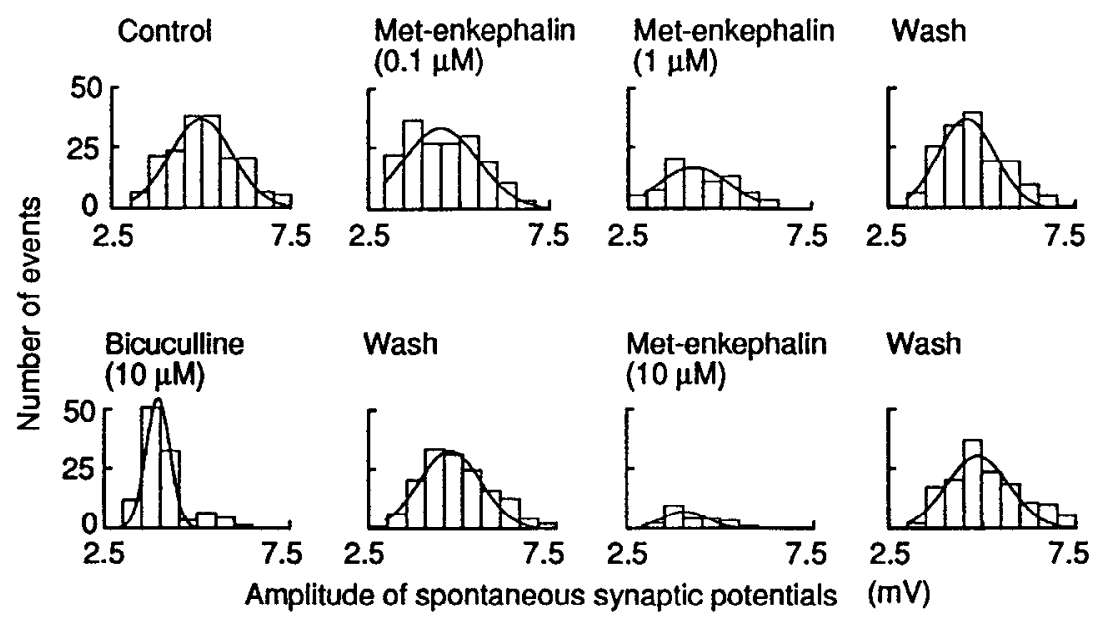

Figure 3. A, Amplitude histograms of the spontaneous synaptic potentials (such as shown in Fig. 2) illustrate that $\left[\mathrm{Met}^{5}\right]$ enkephalin reduces their frequency whereas bicuculline reduces their amplitude. Ordinate is the number of events counted in $50 \mathrm{sec}$ recording pcriods, scparated by amplitude into $0.5 \mathrm{mV}$ bins. The smooth curves are Gaussian functions fitted by leastsquares minimization. In this cell, 100 nM $\left[\mathrm{Met}^{5}\right]$ enkephalin had almost no effect, but $1 \mu \mathrm{M}\left[\mathrm{Met}^{5}\right]$ enkephalin reduced the number of events without significantly changing the shape of the distribution. Bicuculline reduced the mean amplitude but not the total number of events. $B$, Concentration-response curves show that similar concentrations of $\left[\mathrm{Met}^{5}\right]$ enkephalin are effective to reduce the frequency of spontaneous postsynaptic potentials and to hyperpolarize secondary neurons. Higher concentrations are required to reduce the amplitude of electrically evoked $\mathrm{GABA}_{\mathrm{A}}$-mediated synaptic potentials (shown by the open squares). Evoked potentials were recorded in the presence of $10 \mu \mathrm{M} C N Q X$ and $30 \mu \mathrm{M}$ APV. Results are expressed as mean \pm SEM for three to nine experiments.

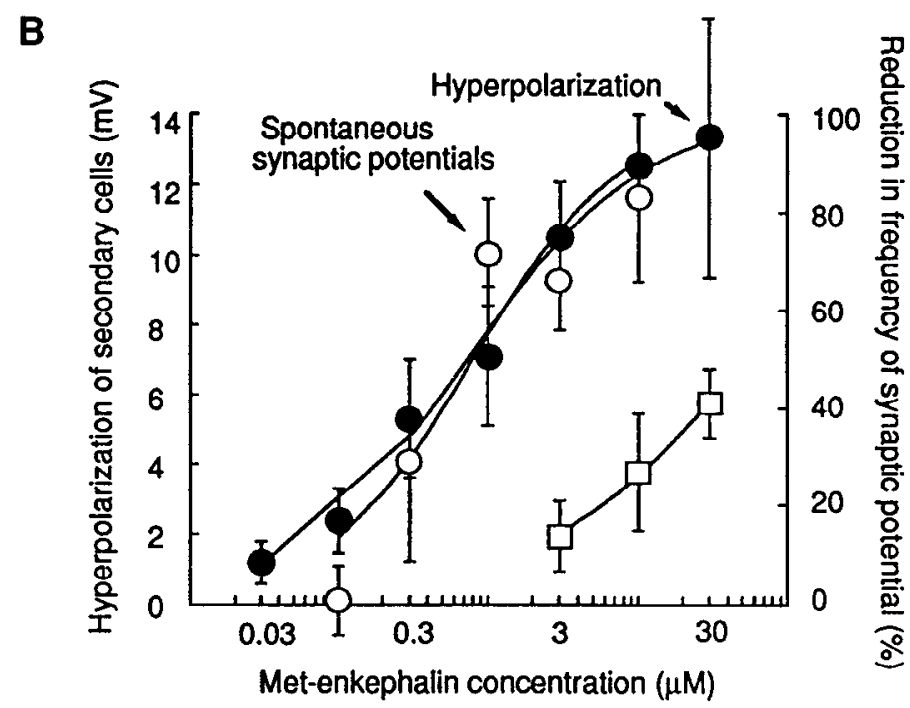

of enkephalin; inhibition was $25 \pm 5 \%(n=6)$ by $3 \mu \mathrm{M}, 30 \pm$ $6 \%(n=6)$ by $10 \mu \mathrm{M}$, and $33 \% \pm 4 \%(n=4)$ by $30 \mu \mathrm{M}$. It should be noted that spontaneous synaptic potentials mediated by excitatory amino acids (i.e., that persisted in bicuculline) or by GABA acting at $\mathrm{GABA}_{\mathrm{B}}$ receptors were not observed, even when the potassium concentration was increased to $10.5 \mathrm{mM}$.

\section{Discussion}

A body of work indicates that the principal cells identified in the present study on the basis of their electrophysiological properties correspond to dopamine-containing neurons (Grace and Onn, 1989; Johnson and North, 1992; Yung et al., 1991) where-
Figure 4. DAMGO excites a principal VTA neuron when the recording is made with an electrode containing potassium acetate. Spontaneous hyperpolarizing synaptic potentials $\left(\mathrm{GABA}_{\mathrm{A}}\right.$ mediated) can be seen that were not present until the potassium concentration of the superfusing solution was increased to 8.5 mM. The DAMGO-induced excitation is mimicked by bicuculline, indicating that it results from inhibition of tonically active inhibitory interneurons.

\section{DAMGO (1 $\mu \mathrm{M})$}

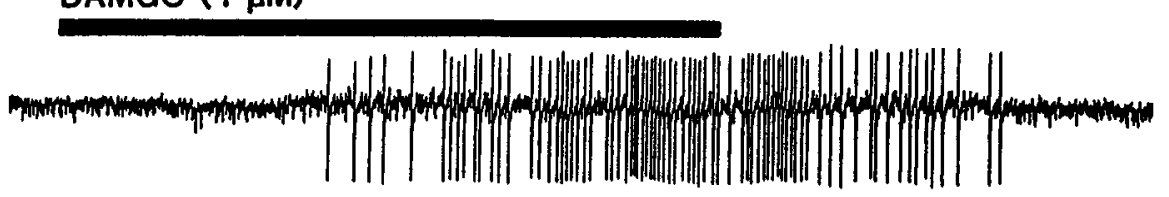

Bicuculline $(30 \mu \mathrm{M})$

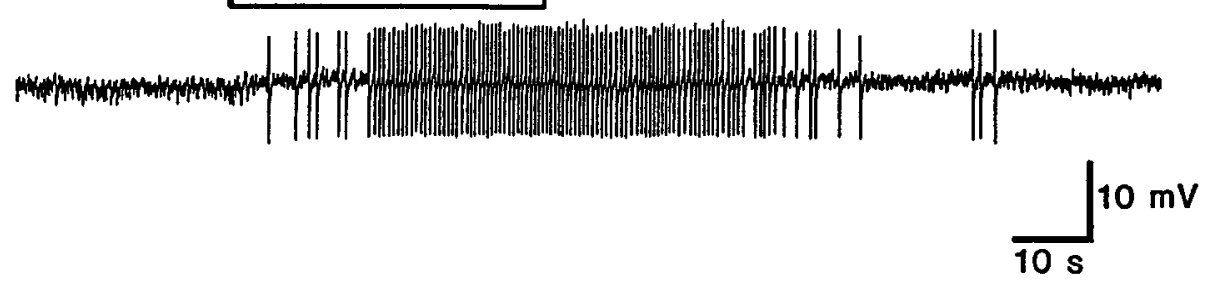


as the secondary cells do not contain dopamine. It is not known whether the secondary cells include nondopamine projection neurons, but they are presumed to include the GABA-containing interneurons known to exist in the VTA (Mugnaini and Oertel, 1985). The finding that opioids hyperpolarize local interneurons is consistent with results in the hippocampus and olfactory bulb (Nicoll et al., 1980; Madison and Nicoll, 1988); the finding that they do so by increasing the membrane potassium conductance is consistent with results in many mammalian neurons (reviewed by North, 1992).

It has been generally inferred that hyperpolarization of inhibitory interneurons accounts for the excitation of hippocampal pyramidal cells (Nicoll et al., 1977; Zieglgansberger et al., 1979; Lee et al., 1980), and consistent with this is the finding that $\mathrm{GABA}_{\mathrm{A}}$-mediated synaptic potentials recorded from pyramidal cells are reduced by opioids (Siggins and Zieglgansberger, 1981). Four results of the present work converge on the conclusion that in the case of the VTA, the dopamine-containing output neurons are excited through disinhibition. First, the spontaneously occurring bicuculline-sensitive synaptic potentials presumably arise from depolarization of local interneurons that have their cell bodies in the tissue slice. There are GABAcontaining cells within the slice (Mugnaini and Oertel, 1985), and TTX blocks their discharge (S. W. Johnson and R. A. North, unpublished observation). It is also consistent with the absence of any spontaneously occurring excitatory synaptic potentials, because the cell bodies of those afferents would be lost when the slice is prepared (Christie et al., 1985). Second, opioids reduced the frequency rather than the amplitude of spontaneous GABA-mediated synaptic potentials. This implies that the opioids act to hyperpolarize the cell body rather than to reduce the amount of GABA released per action potential reaching the release site. Third, similar concentrations of opioids hyperpolarized secondary cells and reduced the synaptic potential frequency (Fig. $3 B$ ), and the $\mu$-receptor was involved in each case. The similarity in the effective concentrations of [ $\left.\mathrm{Met}^{5}\right]$ enkephalin could be fortuitous. A complete inhibition of cell firing would be expected to occur with a hyperpolarization of only a few millivolts; however, a direct comparison is difficult because the potassium concentration was $2.5 \mathrm{~mm}$ when hyperpolarization was measured, but $6.5-10.5 \mathrm{~mm}$ in studies of inhibition of spontaneous synaptic potentials. Fourth, in circumstances in which the local GABA synaptic input was actually inhibitory (electrodes containing potassium acetate), opioids excited the dopamine cells.

Opioids were relatively ineffective in reducing the amplitude of electrically evoked synaptic potentials mediated by $\mathrm{GABA}_{\mathrm{A}}$ receptors. One possible explanation is that the electrical field stimulation so intensely depolarizes the interneurons that a large hyperpolarization (produced by a high opioid concentration) is required to overcome it (see North and Tonini, 1977). Another possibility is that electrical stimulation of the slice recruits GABA-containing fibers that do not originate in local interneurons and they are less sensitive or insensitive to opioids.

It is proposed that, in vivo, secondary cells tonically inhibit dopamine-containing cells and this tonic inhibition is released by opioids acting at $\mu$-receptors to increase potassium conductance. The ability to increase the release of dopamine in limbic target areas such as the nucleus accumbens has been suggested to be a common feature of pharmacologically disparate drugs of abuse (Di Chiara and Imperato, 1988; Liebman and Cooper, 1989). For cocaine, this would occur by inhibiting reuptake in the accumbens (Wise, 1984; Uchimura and North, 1990). In the case of nicotine, a direct excitation of dopamine neuron cell bodies has been shown (Grenhoff et al., 1986; Calabresi et al., 1989). The present work indicates that opioids also fit within the dopaminergic hypothesis of reward but that the excitation of dopamine neurons results from inhibition of local GABA interneurons.

\section{References}

Bozarth MA, Wise RA (1981a) Intracranial self-administration of morphine into the ventral tegmental area in rats. Life Sci 28:551555

Bozarth MA, Wise RA (1981b) Heroin reward is dependent on a dopaminergic substrate. Life Sci 29:1881-1886.

Calabresi P, Lacey MG, North RA (1989) Nicotinic excitation of rat ventral tegmental neurones in vitro studied by intracellular recording. Br J Pharmacol 98:135-140.

Christie MJ, Bridge S, James LB, Beart PM (1985) Excitotoxin lesions suggest an aspartatergic projection from rat medial prefrontal cortex to ventral tegmental area. Brain Res 333:169-172.

Corbett D, Wise RA (1980) Intracranial self-stimulation in rclation to the ascending dopaminergic systems of the midbrain: a moveable electrode mapping study. Brain Res 185:1-15.

Di Chiara G, Imperato A (1988) Drugs abused by humans preferentially increase synaptic dopamine concentrations in the mesolimbic system of freely moving rats. Proc Natl Acad Sci USA 85:5274-5278.

Dilts RP, Kalivas PW (1989) Autoradiographic localization of $\mu$-opioid and neurotensin receptors within the mesolimbic dopamine system. Brain Res 488:311-327.

Fibiger HC, Phillips AG (1986) Reward, motivation, cognition: psychobiology of mesotelencephalic dopamine systems. In: Handbook of physiology, Sec I, Vol 4, pp 647-675

Fibiger HC, LePiane FG, Jakubovic A, Phillips AG (1987) The role of dopamine in intracranial self-stimulation of the ventral tegmental area. J Neurosci 7:3888-3896.

Grace AA, Bunney BS (1980) Nigral dopamine neurons: intracellular recording and identification with $\mathrm{L}$-dopa injection and histofluorescence. Science 210:654-656.

Grace AA, Bunney BS (1983) Intracellular and extracellular electrophysiology of nigral dopaminergic neurons. 1 . Identification and characterization. Neuroscience 10:301-315.

Grace AA, Onn S-P (1989) Morphology and electrophysiological properties of immunocytochemically identified rat dopamine neurons recorded in vitro. J Neurosci 9:3463-3481.

Grenhoff J, Aston-Jones G, Svensson TH (1986) Nicotinic effects on the firing patterns of midbrain dopamine neurons. Acta Physiol Scand 128:351-358.

Gulya K, Pelton JT, Hruby VJ, Yamamura HI (1986) Cyclic somatostatin octapcptide analogues with high affinity and selectivity toward $\mathrm{mu}$ opioid receptors. Life Sci 38:2221-2229.

Gysling K, Wang R (1983) Morphine-induced activation of A10 dopamine neurons in the rat. Brain Res 277:119-127.

Johnson SW, North RA (1992) Two types of neurone in the rat ventral tegmental area and their synaptic inputs. J Physiol (Lond), in press.

Lacey MG, Mercuri NB, North RA (1989) Two cell types in rat substantia nigra zona compacta distinguished by membrane properties. J Neurosci 9:1233-1241.

Lee HK, Dunwiddie T, Hoffer B (1980) Electrophysiological interactions of enkephalins with neuronal circuitry in the rat hippocampus. II. Effects on interneuron excitability. Brain Res 184:331-342.

Liebman JM, Cooper SJ (1989) The neuropharmacological basis of reward. Oxford: Oxford UP.

Madison DV, Nicoll RA (1988) Enkephalin hyperpolarizes interneurones in the rat hippocampus. J Physiol (Lond) 398:123-130.

Matthews RT, German DC (1984) Electrophysiological evidence for excitation of rat ventral tegmental area dopamine neurons by morphine. Neuroscience 11:617-625.

Mihara S, North RA (1986) Opioids increase potassium conductance in guinea-pig submucous neurones by activating $\delta$-receptors. $\mathrm{Br} \mathrm{J}$ Pharmacol 88:315-322.

Miyake M, Christie MJ. North RA (1989) Single potassium channels opened by opioids in rat locus coeruleus neurons. Proc Natl Acad Sci USA $86: 3419-3422$. 
Morita K, North RA, Tokimasa T (1982) The calcium-activated potassium conductance in guinea-pig myenteric neurones. J Physiol (Lond) 329:341-354.

Mugnaini E, Oertel WH (1985) An atlas of the distribution of GABAergic neurons and terminals in the rat CNS as revealed by GAD immunohistochemistry. In: Handbook of chemical neuroanatomy, Vol 4 (Bjorklund A, Hokfelt T, eds), p 436. Amsterdam: Elsevier.

Nicoll RA, Siggins GR, Ling N, Bloom FE, Guillemin R (1977) Neuronal actions of endorphins and enkephalins among brain regions: a comparative microiontophoretic study. Proc Natl Acad Sci USA 74: 2584-2588

Nicoll RA, Alger BE, Jahr CE (1980) Enkephalin blocks inhibitory pathways in the mammalian CNS. Nature 287:22-25.

North RA (1992) Opioid actions on membrane ion channels. In: Handbook of experimental pharmacology (Herz A, Simon EJ, Akil $\mathrm{H}$, eds), in press. Amsterdam: Springer.

North RA, Tonini $M$ (1977) The mechanism of action of narcotic analgesics in the guinea-pig ileum. Br J Pharmacol 61:541-549.

North RA, Williams JT, Surprenant A, Christie MJ (1987) $\mu$ and \& opioid receptors both belong to a family of receptors which couple to a potassium conductance. Proc Natl Acad Sci USA 84:5487-5491.

Nowycky MC, Walters JR, Roth RH (1978) Dopaminergic neurons: effect of acute and chronic morphine administration on single cell activity and transmitter metabolism. J Neural Trans 42:99-116.

Paxinos G, Watson C (1986) The rat brain in stereotaxic coordinates. San Diego: Academic.

Phillips AG, Fibiger HC (1978) The role of dopamine in maintaining intracranial self-stimulation in the ventral tegmentum, nucleus accumbens, and medial prefrontal cortex. Can J Psychol 32:58-66.

Phillips AG, LePiane FG (1980) Reinforcing effects of morphine mi- croinjection into the ventral tegmental area. Pharmacol Biochem Behav 12:965-968.

Phillips AG, LePiane FG, Fibiger HC (1983) Dopaminergic mediation of reward produced by direct injection of enkephalin into the ventral tegmental area of the rat. Life Sci 33:2505-2511.

Portoghese PS, Sultana M, Takemori AE (1988) Naltrindole, a highly selective and potent non-peptide delta opioid receptor antagonist. Eur J Pharmacol 146:185-186.

Siggins GR, Zieglgansberger W (1981) Morphine and opioid peptides reduce inhibitory synaptic potentials in hippocampal pyramidal cells in vitro without alteration of membrane potential. Proc Natl Acad Sci USA 78:5235-5239.

Smith JE, Lane JD (1983) Brain neurotransmitter turnover correlated with morphine self-administration. In: The neurobiology of opiate reward processes, Chap 13, p 361. Amsterdam: Elsevier.

Uchimura N, North RA (1990) Cocaine actions on rat nucleus accumbens neurones in vitro. Br J Pharmacol 99:736-740.

Williams JT, Egan TM, North RA (1982) Enkephalin opens potassium channels in mammalian central neurones. Nature 299:74-77.

Wise RA (1984) Neural mechanisms of the reinforcing action of cocaine. Res Monogr Natl Inst Drug Abuse 50:15-33.

Wise RA (1988) Psychomotor stimulant properties of addictive drugs. Ann NY Acad Sci 537:228-234.

Yung WH, Hausser MA, Jack JJB (1991) Electrophysiology of dopaminergic and non-dopaminergic neurones of the guinea-pig substantia nigra pars compacta in vitro. J Physiol (Lond) 436:643-668.

Zieglgansberger W, French ED, Siggins GR, Bloom FE (1979) Opioid peptides may excite hippocampal pyramidal neurons by inhibiting adjacent inhibitory interneurons. Science 205:415-417. 